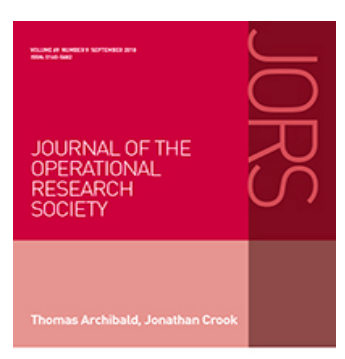

Journal of the Operational Research Society

\title{
Decision analysis in referrals of children and adolescent victims of violence: An ANP approach
}

Hugo Henrique dos Santos, Regiane Máximo de Souza \& Aílton Souza Aragão

To cite this article: Hugo Henrique dos Santos, Regiane Máximo de Souza \& Ailton Souza Aragão (2018) Decision analysis in referrals of children and adolescent victims of violence: An ANP approach, Journal of the Operational Research Society, 69:9, 1483-1492, DOI: 10.1080/01605682.2017.1404186

To link to this article: https://doi.org/10.1080/01605682.2017.1404186

册 Published online: 14 Dec 2017.

Submit your article to this journal $\pi$

山 Article views: 66

View Crossmark data ¿ 


\title{
Decision analysis in referrals of children and adolescent victims of violence: An ANP approach
}

\author{
Hugo Henrique dos Santos ${ }^{a}$, Regiane Máximo de Souza a and Aílton Souza Aragão ${ }^{b}$ \\ aSchool of Engineering, São Paulo State University (Unesp), Bauru, São Paulo, Brazil; bepartment of Public Health, Federal University of \\ Triangulo Mineiro, Uberaba, Brazil
}

\begin{abstract}
The information on violence against children and adolescents in institutions is limited to varying degrees, resulting in inadequate reporting and referrals to safety nets. This paper therefore aims to develop a care protocol that helps institutions in the Brazilian cities of Uberaba, Minas Gerais, and Bauru, São Paulo, to manage reports of violence against children and adolescents. The research used the Analytic Network Process Method (ANP) to improve the flow of victim referrals, making decisions according to the right violated and the type of violence involved. $A$ survey showed that, from a general point of view, the health sector should be a priority point of referral for victims. In the specific cases of neglect and physical violence, social care and Child Protective Services are the priority sectors, respectively. The health sector is the priority for cases of psychological violence and sexual violence.
\end{abstract}

\section{ARTICLE HISTORY}

Received 18 April 2017 Accepted 30 October 2017

\section{KEYWORDS}

Violence; analytic network process; decisions support systems

\section{Introduction}

The current situation and the history of violence against children and adolescents in Brazil highlights a paradox in the country: legislation is very advanced in terms of protection and prevention of violence, but social indicators show that many children and adolescents live in precarious conditions and are commonly exposed to violence (Brasil, 2013; Rizzini \& Pilotti, 2011).

According to the World Health Organization (WHO) violence can be defined as the intentional use of physical force or power, threaten or actual, against oneself, another person, or against a group or community, which either results in or has a high likelihood of resulting in injury, death, psychological harm, maldevelopment, or deprivation (Krug, Dahlberg, Mercy, Zwi, \& Lozano, 2002). Violence against children and adolescents is characterised by any physical, sexual, or psychological damage caused by parents, relatives, or other members of society (Minayo, 2001). Despite implementing the Children and Adolescents Statute (Estatuto da Criança e Adolescente - ECA) in 1990, the number of cases of violence against children and adolescents is increasing in Brazil (Waiselfisz, 2012). The statute established the rights held by children and adolescents and the triplicate responsibility of the family, society, and the government in combating violence, however, violence is still characterised as a problem of individual and collective vulnerability (Ayres, Junior, Calazans, \& Filho, 2003).

With the enactment of the statute, Child Protective Services were institutionalised in Brazilian municipalities with the purpose of ensuring accountability for acts of violence committed against children and adolescents, defending their rights, and providing care under a wide range of demands. The statute also required the adoption of safety nets involving professionals from various sectors such as health, social care, education, the legal system, and non-governmental organisations, among others (Aragão, 2011). These safety nets provide Child Protective Services with a centralised space for referred cases of violence, but often lead to an overload of work and decisions, isolating Child Protective Services from other sectors and hindering the referrals' flow. This overload ends up causing setbacks in Protective Services referrals, often individualising the problem and not identifying the causal connection between the violence committed and the right violated. This type of problem can cause an incorrect reporting flow, which is essential to the continuity of actions within the safety net, affecting cases directly (Aragão, 2011; Apostólico, Nóbrega, Guedes, Fonseca, \& Egry, 2012; Bannwart \& Brino, 2011; Lima \& Deslandes, 2015; Njaine, 1997).

The objective of this study is to develop a protocol to assist institutions in the Rights Assurance System 
(from two municipalities) to manage reports of violence against children and adolescents using the Analytic Network Process Method (ANP). This model aims to correlate rights, types of violence, and care sectors in order to improve the referral of reports to safety nets. The research was conducted in the cities of Bauru, SP, and Uberaba, MG. Over the last year, Bauru has seen numerous cases of domestic violence, sexual violence, and other violent acts against children and adolescents, according to data from DATASUS, while Uberaba has one of the highest rates of reported cases of physical and sexual violence in Brazil (Waiselfisz, 2012).

The key task in seeking to improve the referral of individuals within the safety net is to correlate the classifications of violence developed and used by Child Protective Services with the fundamental rights described in ECA and with the correct referral of reports to the care network. The ANP is a mathematical tool capable of creating complex relations between various elements in order to improve referrals. One of the broadest decision-making methodologies in the literature is Multiple Criteria Decision-Making. It is used in studies across a wide range of fields such as energy and the environment, business, economics, production, etc., and its approaches provide understanding and quality in decision-making processes by using efficient techniques that rationally explain all the ways of obtaining better alternatives (Mardani et al., 2015). ANP is one of the Multi Criteria Decision Making (MCDM) methods introduced by Thomas L. Saaty in 1993, and is used to derive judgment priorities for decision-makers. The method is structured as a network composed of goals, criteria, and alternatives allocated in clusters, where internal and external comparisons are made between clusters and between all the related elements, analytically determining the decision-making process (Saaty, 2009, 2013).

ANP allows to relate several decision criteria (dependent on each other) to a given phenomenon in a network, in this case, care for victims of violence. Therefore, to relate and analyse the rights of children and adolescents to a typology of violence exposes the consequences of this violence on the integral development of the victim over time. Adoption of the ANP will allow for decision-makers to refer those victims to the SGDCA institutions in a consistent manner. There are dependences between rights and violence. For example, a person who suffers sexual violence has great possibilities to suffer psychological disorders and relationship problems. A person who suffers any violence typology can have some violated rights in the same time. These comparisons don't be possible in a hierarchical structure, this complex problem can be better explored in a network structure with a complete mapping of the decisions criteria.

Studies that use a quantitative approach are more often found in research into the most frequent types of violence, the profile of the offenders, the frequency of violence, and the adolescents victimised, using descriptive statistics (Apostólico et al., 2012; Franzin et al., 2014; Ju \& Lee, 2010; Veronese, Castiglioni, Barola, \& Said, 2012), logistic regression analysis (Hamilton \& Worthen, 2010), and correlation analyses (Meinck, Cluver, Boyes, \& Mhlongo, 2015). It is important to emphasise that no studies into violence using multi-criteria analysis were found in the literature to date. The state of the art demonstrates that the contribution of the Multicriteria Analysis Method to the analysis of social issues allows for a comprehensive look at the referrals of the victims of violence and this study presents a great contribution to literature.

The ANP method has been widely used in the literature. Applications include Balanced Scorecard perspectives (BSC) (Yüksel \& Dağdeviren, 2010); Research and Development project selection (Meade \& Presley, 2002); application with SWOT analysis (Sevkli et al., 2012; Yuksel \& Dagdeviren, 2007); use in conjunction with fuzzy techniques for supplier selection (Gencer \& Gürpinar, 2007; Vinodh, Anesh, \& Gautham, 2011); selection of the best risk assessment technique for maintenance professionals (Chemweno, Pintelon, Van Horenbeek \& Muchiri, 2015); and applications in the green supply chain (Lin, Tseng, Chiu, \& Wang, 2014; Wu \& Barnes, 2016). These are just some examples of the wide applicability of the method, demonstrating the characteristics of a powerful decision-making tool used for very complex problems.

\section{Methodology}

\subsection{Formulation of the problem and development of the ANP network}

The first step in formulating the ANP network is to identify the most important decision-making elements (Saaty \& Vargas, 2006). In this case, the network's goal was to improve performance in referring victims of violence. Although foreseen in ECA, the System of Guarantee of Rights of the cities studied has peculiarities and similarities. They are the existence of public facilities acting in isolation, without the agreement of common protocols of violence notification, the emergency action that prevents the creation of strategies to prevent violence. Thus, the creation of an attendance/referencing protocol with ANP for each type of violence, which considers the type of right violated, can allow greater speed in the activation of the care sectors.

Figure 1 shows the established reference model. Three clusters were created to analyse the problem: rights violated, types of violence, and care sectors. The rights violated were determined according to the ECA: Right to Life and Health (R1); Right to Freedom, Respect, and Dignity (R2); Right to Family (R3); Right to Education, Culture, Sport, and Recreation (R4); and Right to Professionalism and Protection at Work (R5). The types 


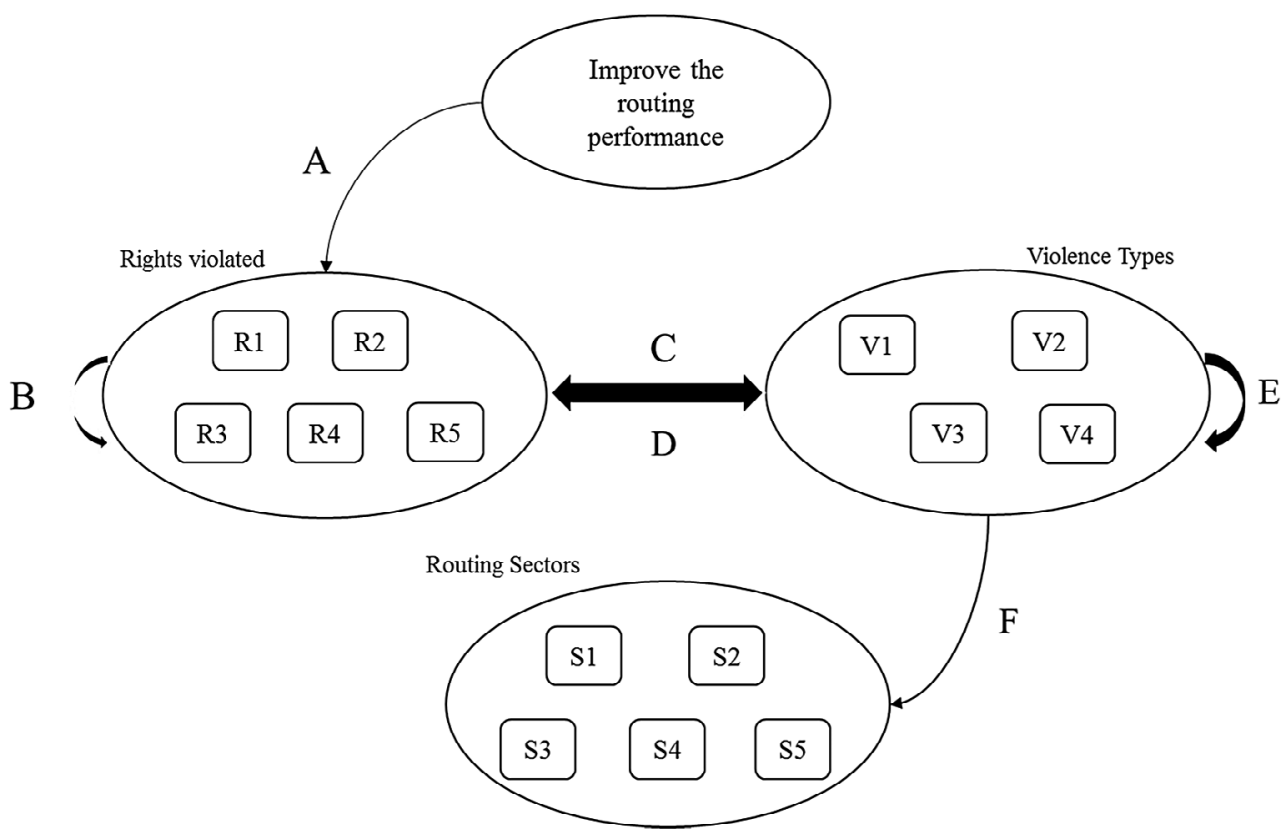

Figure 1. ANP reference model.

of violence were: Family Neglect (V1); Physical Violence (V2); Psychological Violence (V3); and Sexual Violence (V4). The typologies of violence are described in Table 1. Finally, the cluster representing the referral alternatives, comprising the main sectors where children and adolescents receive care, were: Social Care (S1); Education and Culture (S2); Health (S3); the Legal System (S4); and Child Protective Services (S5). Connections A, B, $\mathrm{C}, \mathrm{D}, \mathrm{E}$, and $\mathrm{F}$ show the relations between the clusters.

\subsection{Paired comparisons and consistency analysis}

All the related elements are paired and compared according to Saaty's Fundamental Scale, presented in Table 2. A response consistency ratio is calculated for each question. The ANP method considers 0.10 as the maximum inconsistency level (Saaty, 1990). Only consistent questions were considered for analysis. The following equations are used to calculate the consistency ratio:

$$
\begin{gathered}
\mathrm{CI}=\left(\lambda_{\max }-n\right) / n-1 \\
\mathrm{CR}=\mathrm{CI} / \mathrm{RI}
\end{gathered}
$$

The Consistency Index (CI) is calculated based on the value of each matrix, represented by $\lambda_{\text {max }}$. Element $n$ represents the order of the decision matrix. The Consistency Ratio (CR) is calculated by dividing the CI by the Random Index (RI), which determines a random index according to the order of the matrix, as shown in Table 3.

\subsection{Aggregation of priorities}

The Aggregation of Individual Priorities method (AIP) was used to aggregate the priorities for each consistent question. AIP is used when individuals act individually in their own right, where there is a need to obtain priorities for each decision-maker in order to analyse the problem. The aggregation is determined by the geometric mean of each decision-maker's priorities (Altazurra, Moreno-Jiménez, \& Salvador, 2007; Forman \& Peniwati, 1998). The aggregations were performed only for the questions identified as consistent in the analysis.

\subsection{Construction of the supermatrix}

The supermatrix is a specific element of the ANP (Saaty, 2009). Matrices A, B, C, D, E, and F from Figure 1 were weighted according to the weight of each decision cluster and allocated to a supermatrix which was multiplied $n$ times, until all the elements in each row had the same

\begin{tabular}{|c|c|}
\hline Violence types & Description \\
\hline Physical violence & $\begin{array}{l}\text { Use of physical force that may cause harm, injuries, disabilities, or any other physical damage as a result of various agents, and } \\
\text { can be found in a range of contexts across society (Assis \& Deslandes, 2006; Minayo, 2001) }\end{array}$ \\
\hline Sexual violence & $\begin{array}{l}\text { One of the most serious manifestations of violence often perpetrated by people close to the victim, within their own homes, } \\
\text { or even by strangers in public, and most represented in the form of rape. Such violence is characterised by sexual abuse and } \\
\text { exploitation (Costa et al., 2007; Felizardo et al., 2006) }\end{array}$ \\
\hline Psychological violence & $\begin{array}{l}\text { Psychological abuse exercised by adults against children, damaging their self-esteem and making it difficult for them to reach } \\
\text { their potential, worsening psychological and social problems (Assis \& Avanci, 2006) }\end{array}$ \\
\hline Neglect & $\begin{array}{l}\text { Neglect is characterised as abandonment or lack of family care regarding issues such as health, education, clothing, or food. } \\
\text { In other words, anything that the family fails to provide in order to care for the physical, social, and emotional needs of the } \\
\text { child (Minayo, 2001) }\end{array}$ \\
\hline
\end{tabular}

Table 1. Types and characteristics of violence. 
Table 2. Saaty fundamental scale.

\begin{tabular}{lll}
\hline & Definition & Explanation \\
\hline 1 & $\begin{array}{l}\text { Equal importance } \\
\text { Moderate } \\
5\end{array}$ & $\begin{array}{l}\text { Two activities contribute equally to the goal } \\
\text { Experience and judgement slightly favour one activity over another } \\
\text { Experience and judgement strongly favour one activity over } \\
\text { another } \\
\text { One activity is favoured very strongly over another and its domi- } \\
\text { nance is demonstrated in practice } \\
\text { The evidence favouring one activity over another is of the highest } \\
\text { possible order of affirmation }\end{array}$ \\
$\begin{array}{lll}\text { Extreme } & \text { Intermediate values } & \text { Used to represent a compromise between the preferences listed } \\
\text { above }\end{array}$ & $\begin{array}{l}\text { If activity } i \text { is assigned one of the above non-zero numbers when compared to activity } j \text {, then } j \text { has a reciprocal value when compared to } i \\
\text { Reciprocity }\end{array}$
\end{tabular}

Table 3. Random index.

\begin{tabular}{llllllllll}
\hline$n$ & 1 & 2 & 3 & 4 & 5 & 6 & 7 & 8 & 9 \\
\hline Random index & 0 & 0 & .52 & .89 & 1.11 & 1.25 & 1.35 & 1.40 & 1.45 \\
\hline
\end{tabular}

value, known as the limit supermatrix. The supermatrix applied in this study can be seen below. After obtaining the limit supermatrix, the weights were normalised and further weights were extracted for the criteria and the final priorities of each care sector.

\begin{tabular}{|c|c|c|c|c|}
\hline & Goal & Criteria & Subcriteria & Alternatives \\
\hline Goal & 0 & 0 & 0 & 0 \\
\hline Criteria & A & B & D & 0 \\
\hline Subcriteria & 0 & $\mathrm{C}$ & E & 0 \\
\hline Alternatives & 0 & 0 & $\mathrm{~F}$ & 0 \\
\hline
\end{tabular}

\subsection{Sensitivity analysis}

Sensitivity analysis is the last stage of the ANP methodology, and its function is to classify the alternatives according to the variation or exclusion of certain criteria. The weights of the alternatives are highly dependent on certain criteria, so alternative scenarios can be created by varying the criteria that affect the problem resolution the most. Normally, the criterion with the greatest weight is used as the analysis variant (Chang, $\mathrm{Wu}, \mathrm{Lin}, \&$ Chen, 2007; Ishizaka \& Labib, 2011).

\section{Case study}

\subsection{General analysis}

The first step in analysing the questionnaires in the ANP method is to calculate the consistency of the responses. The 13 (thirteen) questionnaires were subjected to this calculation and inconsistent questions were excluded from the analysis. Experts from the cities considered in the study, were surveyed to identify the best sectors. The decision-support group composed of professionals from the legal system, such as a Children and Youth prosecutor and judge, social workers, professionals from the Social Care Reference Centre (SCRC) and the Specialist Social Care Reference Centre (SSCRC), members of non-governmental organisations (NGOs), and health professionals. In total, 13 (thirteen) ANP questionnaires were used to research safety nets in the two cities.
After this procedure, the remaining steps of the method were applied: aggregation of the consistent questions, formulation of the decision matrices, allocation of the matrices in the supermatrix, weighting of the supermatrix, calculation of the limit matrix, and normalisation of the results. The weights of the rights violated, the acts of violence, and the care sectors were then extracted from the limit matrix. Table 4 shows the results of the study's general analysis (considering all types of violence).

Based on the above results, considering all types of violence, the health sector is identified as the priority sector for the care of children and adolescents, followed by Child Protective Services and Social Care. This result, health sector as a priority, may also be related to the weights of the types of violence and rights violated given by the analysis. In this analysis, Family Neglect (O1) was the type of violence with the highest weight, so this classification may be linked to this hypothesis. To verify this result, a sensitivity analysis was performed. The weight assigned to Family Neglect was varied from 0.1 to 0.9 while observing the behaviour of the alternatives, showing some alternative scenarios in the ranking of priorities. The differences found can be seen in Table 5 .

Table 4. General analysis results.

\begin{tabular}{lc}
\hline Rights violated & Weights \\
\hline Right to life and health & 0.2514 \\
Right to freedom, respect, and dignity & 0.2868 \\
Right to family & 0.2028 \\
Right to education, culture, sport, and recreation & 0.1464 \\
Right to professionalisation and protection at work & 0.1126 \\
Types of violence & Weights \\
Family neglect & 0.3070 \\
Physical violence & 0.1898 \\
Psychological violence & 0.2265 \\
Sexual violence & 0.2767 \\
Sectors & Weights \\
Social care & 0.1919 \\
Education and culture & 0.1736 \\
Health & 0.2427 \\
Legal system & 0.1822 \\
Child protective services & 0.2096 \\
\hline
\end{tabular}

Note: The bold values are the most relevant weights in analysis. 
Table 5. Results based on varying weight of neglect.

\begin{tabular}{llllll}
\hline & \multicolumn{5}{c}{ Varying weight of neglect } \\
\hline Sectors & $\mathbf{0 . 1}$ & $\mathbf{0 . 3}$ & $\mathbf{0 . 5}$ & $\mathbf{0 . 7}$ & $\mathbf{0 . 9}$ \\
Social care & 0.169 & 0.191 & 0.213 & 0.236 & 0.258 \\
Education and culture & 0.179 & 0.174 & 0.171 & 0.169 & 0.166 \\
Health & $\mathbf{0 . 2 7 0}$ & $\mathbf{0 . 2 4 4}$ & $\mathbf{0 . 2 1 7}$ & 0.190 & 0.163 \\
Legal system & 0.183 & 0.182 & 0.181 & 0.180 & 0.179 \\
Child protective services & 0.202 & 0.209 & $\mathbf{0 . 2 1 7}$ & 0.225 & 0.233
\end{tabular}

Note: The bold values represents the most relevant weights when the neglect weight varies between 0.1 and 0.9 .

Table 6. Priorities for cases of neglect.

\begin{tabular}{lcc}
\hline & Priorities & Classification \\
\hline Social care & 0.2694 & $1 \mathrm{st}$ \\
Education and culture & 0.1653 & $4 \mathrm{th}$ \\
Health & 0.1501 & $5 \mathrm{th}$ \\
Legal system & 0.1786 & $3 \mathrm{rd}$ \\
Child protective services & 0.2366 & 2nd \\
\hline
\end{tabular}

When the weight of Family Neglect was between 0.1 and 0.4 , the health sector remained the highest care priority. When the weight was 0.5 , Child Protective Services presented the same weight as the health sector (21.7\%), followed by social care (21.3\%). From 0.7 and up, social care becomes the priority sector in the analysis and thus takes priority until the upper limit of the range, as shown in Table 5. The priority of the health sector decreases as the weight assigned to Family Neglect increases, and when that weight is 0.9 , the health sector is the lowest priority sector for care. The results of this general analysis demonstrate the need to verify the priority sectors for each type of violence. The classifications can change dramatically depending solely on the type of violence. Another relevant point highlighted by this analysis is the establishment of care protocols for each type of violence, since each one requires different care demands.
The results in Table 4 show the relevance in analysing the types of violence on a sectorised basis. So, the overall ANP analysis resulted in several individual analyses, as can be seen in the following section.

\subsection{Analysis by type of violence and care protocol}

\subsubsection{Family neglect}

The ANP method analysis identified social care, followed by Child Protective Services and the legal system, as the priority sectors for referring victims of this type of violence. In this analysis, legal experts, social workers, and health professionals established their priorities, since they were the sectors whose answers were consistent with the ANP method. Table 6 presents the priorities and the classification of the sectors.

The health sector appears as the last priority for referral. Those who report cases of neglect do not consider the health sector as competent enough to provide the care needed (Nunes \& Sales, 2016). This result, with the health sector as the lowest priority, reinforces the outcome of the sensitivity analysis conducted for the general classification (Table 4). As shown, the greater the weight assigned to neglect, the lower the priority of the health sector. Thus, the individual analysis of neglect corroborates the alternative scenarios determined in the sensitivity analysis, showing that the social care and Child Protective Services are the sectors most suitable for treating cases of this type of violence. Figure 2 shows the care protocol developed for victims of family neglect.

\subsubsection{Physical violence}

Child Protective Services was designated the highest priority for referrals in cases of physical violence

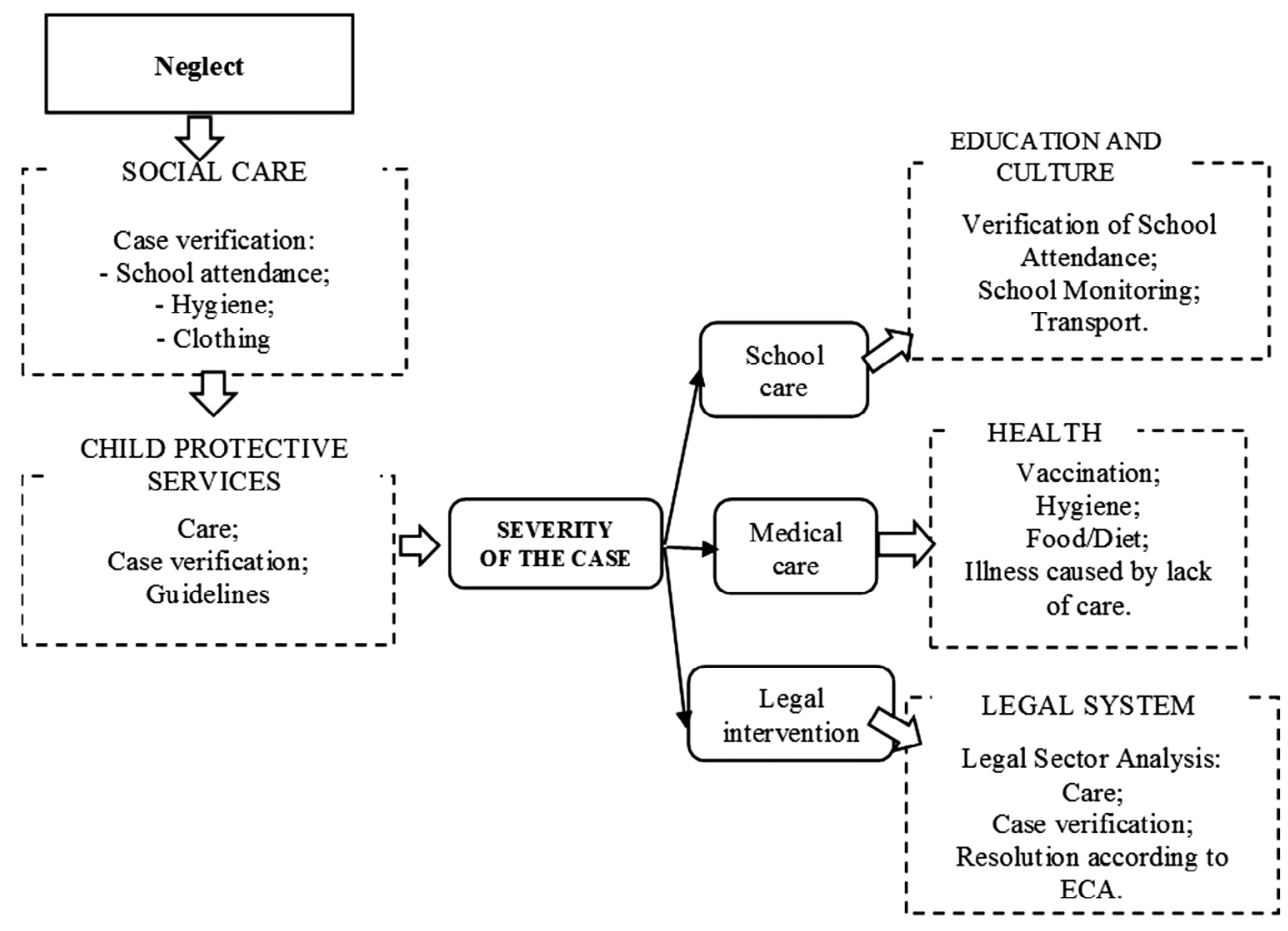

Figure 2. Referrals flow for victims of family neglect. 
Table 7. Priorities for cases of physical violence.

\begin{tabular}{lcc}
\hline & Priorities & Classification \\
\hline Social care & 0.2219 & 2nd \\
Education and culture & 0.1953 & 3rd \\
Health & 0.1801 & 4 th \\
Legal system & 0.1647 & 5 th \\
Child protective services & 0.2379 & $1 \mathrm{st}$ \\
\hline
\end{tabular}

\subsubsection{Psychological violence}

The health sector was identified as the highest priority for victims of psychological violence, followed by education and culture, and then social care. It is noticed in this typology that Child Protective Services and the legal system, Sectors with high frequency of care, did not receive a high priority for referrals. This classification can be interpreted

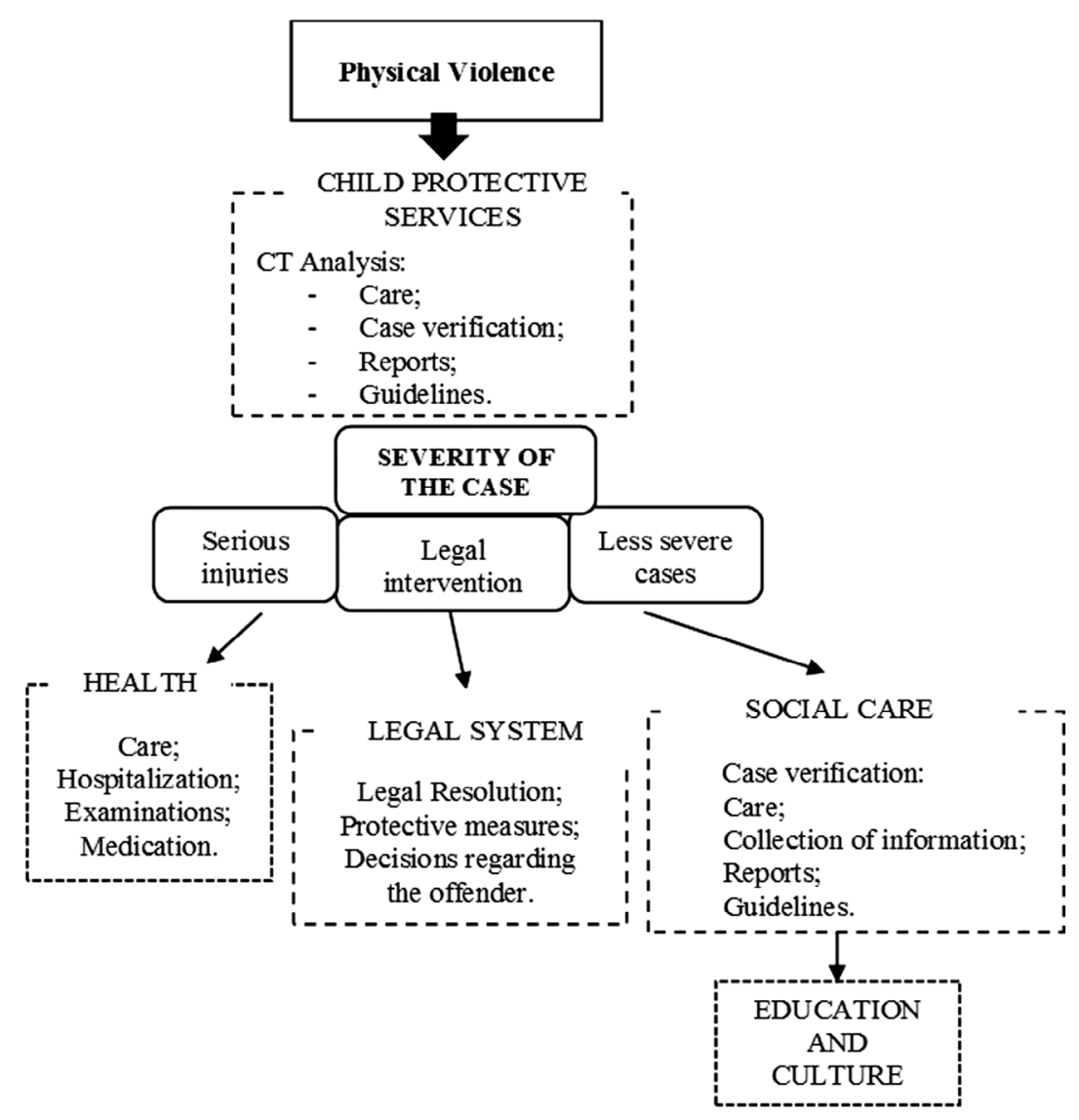

Figure 3. Referrals flow for victims of physical violence.

against children and adolescents, followed by social care. Education and culture was the last of the three key sectors for referral in these cases (Table 7). Even with the classification of the sectors by the ANP, the seriousness of the case should be taken into consideration, and this can directly affect the right referral flow. For example, when children or adolescents have suffered very serious physical injuries, they should be referred to health care services. Establishing the severity classification is an important care process, because it creates urgency criteria for each type of case and gives a structure to care flowcharts and protocols (Pfeiffer, Rosário, \& Cat, 2011).

Education and culture was the third referral priority for victims of physical violence. This result may be associated with the implementation of long-term measures, such as cultural projects and reintegration of victims into the school environment. Figure 3 shows the care protocol for cases of physical violence. as follows: the professionals who answered the question regarding psychological violence understand that health and education represent the main opportunities for detecting these cases. For example, teachers who constantly work with this group often notice signs of psychological violence (Table 8). Skin abnormalities, difficulties with speech, behaviour, and diseases such as obesity are some examples of indicators of this type of violence (Assis, 1994).

Despite the high priority given to the health and education sectors, the level of identification and reporting

Table 8. Priorities for cases of psychological violence.

\begin{tabular}{lcc}
\hline & Priorities & Classification \\
\hline Social care & 0.1717 & 3rd \\
Education and culture & 0.2556 & 2nd \\
Health & 0.2794 & $1 \mathrm{st}$ \\
Legal system & 0.1234 & $5 \mathrm{th}$ \\
Child protective services & 0.1699 & 4th \\
\hline
\end{tabular}

Note: The bold word represent the most relevant sector in analysis. 


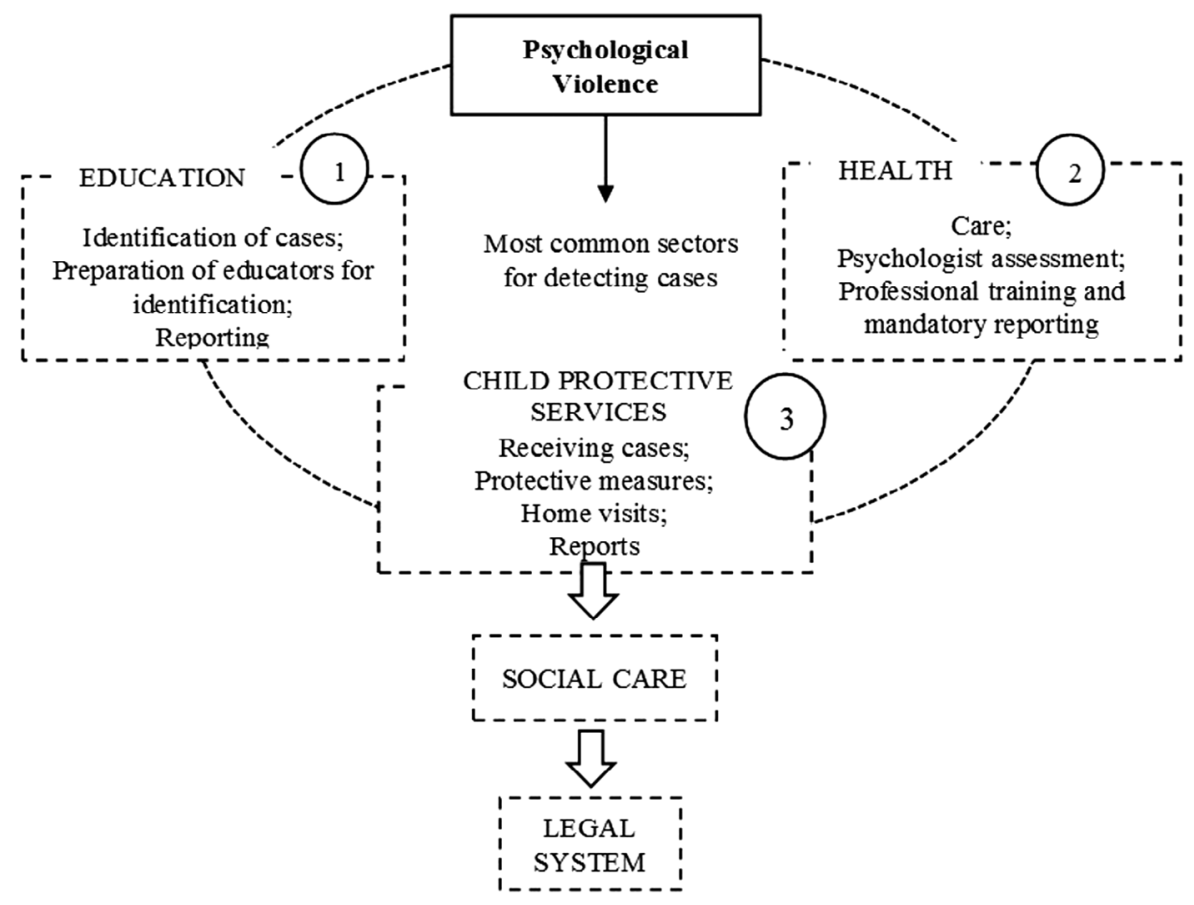

Figure 4. Referrals flow for victims of psychological violence.

by professionals in these sectors with respect to psychological violence is questionable (Faraj, Siqueira, \& Arpini, 2016; Silva, Lunardi, Lunard, Algeri, \& Souza, 2016; Silveira et al., 2016). Social care, the third priority sector in the analysis, is a sector that involves interdisciplinary teams that are better able to solve psychological problems. Training professionals to identify and report cases is the first step to addressing this problem (Figure 4).

\subsubsection{Sexual violence}

Among the various paths to the provision of immediate care in cases of sexual violence, the health sector received the greatest weight in the analysis, followed by the legal system and Child Protective Services, respectively. This classification is shown in Table 9 and demonstrates the importance of immediate care at health services, especially when the victims have suffered sexual abuse. There is often a fragile link between the social sectors and health sectors, leading to a lack of involvement in the allocation of strategies to address this type of violence (Paixão \& Deslandes, 2010).

As illustrated in the classification, the legal system and Child Protective Services are the priority sectors after treatment of victims by health services. The legal system was likely determined as the second priority sector in the analysis due to the need for justice, since sexual abuse is considered one of the most serious forms of violence (Felizardo, Zurcher, \& Melo, 2006).

Child Protective Services was identified as the third referral priority for victims, even being a sector that concentrates most of the care actions from across the range of types of violence presented (Aragão, 2011). There is a lack of cooperation between Child Protective Services and the health and education sectors that hinders the fight against sexual violence and deserves greater attention, because these sectors are considered pillars of public policy (Deslandes \& Campos, 2015). The care protocol for victims of sexual violence is shown in Figure 5.

After the results obtained with the ANP, they were reported to the participants of the study, so that they could validate the relevance of the results in relation to what is experienced in the daily care service in the care sectors. All protocols were validated by the participants.

\section{Conclusion}

The main objective of this research was to develop a protocol to assist institutions in the Rights Assurance System in the municipalities of Uberaba, MG, and Bauru, SP, to manage reports of violence against children and adolescents. The Analytic Network Process method was used to develop the protocols, determining priorities according to each type of violence committed, obtained by working with experts from various sectors that comprise the safety net in both cities. The following results were achieved:

- The health sector was considered the priority care sector for all types of violence, as neglect was identified as the main type of violence in the cases, but the sensitivity analysis showed that the priorities were subject to change depending on the weight assigned to neglect. 
Table 9. Priorities for cases of sexual violence.

\begin{tabular}{lcc}
\hline & Priorities & Classification \\
\hline Social care & 0.1018 & 4th \\
Education and culture & 0.1007 & 5 th \\
Health & 0.3581 & 1st \\
Legal system & 0.2465 & 2nd \\
Child protective services & 0.1929 & 3rd \\
\hline
\end{tabular}

Note: The bold word represent the most relevant sector in analysis.
As noted throughout this paper, intersectoral cooperation between safety net organisations depends on the effectiveness of the reporting procedure. Many sectors are not reporting properly, especially the health and education sectors (Faraj et al., 2016; Silva et al., 2016; Silveira et al., 2016), and these institutions should therefore be studied in further detail, to identify the reasons for
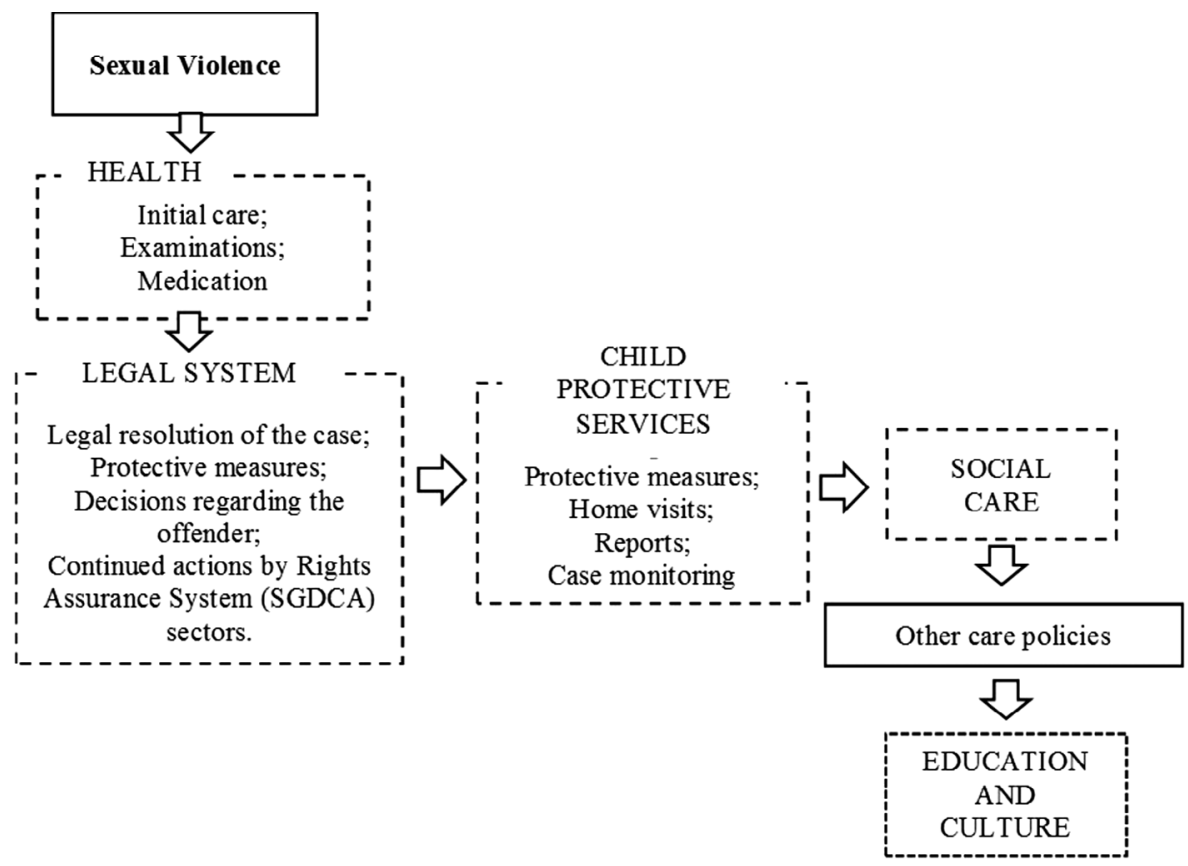

Figure 5. Referrals flow for victims of sexual violence.

- Social care and Child Protective Services were the priority sectors for victims of neglect and physical violence, respectively. The health sector was given the greatest weight psychological and sexual violence.

- These classifications are used as the basis for establishing the care protocols, supported by mathematical tools and aiming to provide a scientific approach to decisions that safety net managers make based on personal feelings and the case. The referral flows developed are able to assist these professionals when receiving reports of cases of violence.

- The study highlights guidelines for the care sectors and identifies indicators to advance public protection policy.

- The study faced serious intersectoral problems with the safety nets, including a lack of communication and systematisation of the cases presented in a database that is used to improve the reporting and referrals processes, particularly in the health and education sectors, corroborating the findings from the literature. the flaws in the reporting process and for the low level of cases reported. Application of Analytic Hierarchy Process (AHP) to identify the main barriers to reporting is a possible option, as well as the study of specific cases.

A limitation of the study was observed in the city of Bauru, because the low participation of the professionals integrating the Rights Guarantee System is a reflection of the little institutional stimulus for a reticular performance. We also observed the difficulties in interpreting the ANP instrument when comparing the analysis criteria. These three limitations corroborate the excessive fragmentation of the city's protection net, which restricted a broader analysis among the sectors involved.

Applications of this analytical structure in other contexts could consider the types of violence and rights, relating them to each other, observing the classifications for cities with higher violence statistics than the ones studied, comparing the priority referral results for each type of violence. Another possibility for future research would be to apply the same model only to Child Protective Services, as a sector that is overburdened with actions and decisions (Aragão, 2011) and has a central 
role in the safety net, asking professionals about the referrals needed and the difficulties communicating and cooperating with other sectors.

\section{Acknowledgements}

The authors would like to thank the anonymous referees for their useful comments and suggestions and CAPES and $\mathrm{CNPq}$ for their financial support.

\section{Disclosure statement}

No potential conflict of interest was reported by the authors.

\section{References}

Altazurra, A., Moreno-Jiménez, J. M., \& Salvador, M. (2007). A Bayesian prioritization procedure for AHPgroup decision making. European Journal of Operational Research, 182(1), 367-382.

Apostólico, M. R., Nóbrega, C. R., Guedes, R. N., Fonseca, R. M. G. S., \& Egry, E. Y. (2012). Characteristics of violence against children in a Brazilian Capital. Revista LatinoAmericana de Enfermagem, 20(2), 266-273.

Aragão, A. S. (2011). Rede de proteção social e promoção de direitos: contribuições do conselho tutelar para a integralidade e a intersetorialidade [Social network of protection and promotion of rights: the contributions of Tutelary Council for integrality and intersectoral]. These: Universidade de São Paulo.

Assis, S. G. (1994). Crescer sem violência: um desafio para os educadores. Rio de Janeiro: CLAVES.

Assis, S. G., \& Avanci, J. Q. (2006). Abuso psicológico e desenvolvimento infantil [Psychological abuse and child development]. In Brasil. Ministério da Saúde (Eds.), Violência faz mal à Saúde (pp. 59-68). Brasília: Ministério da Saúde.

Assis, S. G., \& Deslandes, S. F. (2006). Abuso físico em diferentes contextos de socialização infanto-juvenil [Physical abuse in different contexts of child-socialization]. In C. A. Lima (Ed.), Violência faz mal à saúde (pp. 47-57). Brasília: Ministério da Saúde.

Ayres, J. R., Junior, I. F., Calazans, G. J., \& Filho, H. C. S. (2003). O conceito de vulnerabilidade e as práticas de saúde: novas perspectivas e desafios [The concept of vulnerability and health practices: new perspectives and challenges]. In D. Czeresnia \& C. M. Freitas (Eds.), Promoção da saúde: conceitos, reflexões, tendências (pp. 117-140). Rio de Janeiro: Fiocruz.

Bannwart, T. H., \& Brino, R. F. (2011). Dificuldades enfrentadas para identificar e notificar casos de maustratos contra crianças e/ou adolescentes sob a óptica de médicos pediatras [Difficulties to identify and report cases of abuse against children and adolescents from the viewpoint of pediatricians]. Revista Paulista de Pediatria, 29(2), 138-145.

Brasil. (2013). Ministério da Saúde. VIVA: Sistema de Vigilância de Violências e Acidentes, 2009-2010 e 2011. Brasília: Ministério da Saúde.

Chang, C. W., Wu, C. R., Lin, C. T., \& Chen, H. C. (2007). An application of AHP and sensitivity analysis for selecting the best slicing machine. Computers \& Industrial Engineering, 52(2), 296-307.

Chemweno, P., Pintelon, L., Van Horenbeek, A., \& Muchiri, P. (2015). Development of a risk assessment selection methodology for asset maintenance decision making: An analytic network process (ANP) approach. International Journal of Production Economics, 170, 663-676.

Costa, M. C. O., Carvalho, R. C., Barbara, J. F. R. S., Santos, C. A. S. T., Gomes, W. A., \& Sousa, H. L. (2007). O perfil da violência contra crianças e adolescentes, segundo registros de Conselhos Tutelares: vítimas, agressores e manifestações de violência. Ciência \& Saúde Coletiva, 12(5), 1129-1141.

Deslandes, S. F., \& Campos, D. S. (2015). A ótica dos conselheiros tutelares sobre a ação da rede para a garantia da proteção integral a crianças e adolescentes em situação de violência sexual. Ciência e Saúde Coletiva, 20(7), 2173-2182.

Faraj, S. P., Siqueira, A. C., \& Arpini, D. M. (2016). Notificação da Violência: Percepções de Operadores do Direito e Conselheiros Tutelares. Psicologia: Ciência e Profissão, 36(4), 907-920.

Felizardo, D., Zurcher, E., \& Melo, K. (2006). Violência sexual: conceituação e atendimento. In Brasil. Ministério da Saúde (Eds.), Violência faz mal à Saúde (pp. 69-80). Brasília: Ministério da Saúde.

Forman, E., \& Peniwati, K. (1998). Aggregating individual judgments and priorities with the analytic hierarchy process. European Journal of Operational Research, 108(1), 165-169.

Franzin, L. C. S., Olandovski, M., Vettorazzi, M. L. T., Werneck, R. I., Moysés, S. J., Kusma, S. Z., \& Moysés, S. T. (2014). Child and adolescent abuse and neglect in the city of Curitiba, Brazil. Child Abuse and Neglect, 38(10), $1706-1714$.

Gencer, C., \& Gürpinar, D. (2007). Analytic network process in supplier selection: A case study in an electronic firm. Applied Mathematical Modelling, 31(11), 2475-2486.

Hamilton, M., \& Worthen, M. G. F. (2010). Sex disparities in arrest outcomes for domestic violence. Journal of Interpersonal Violence, 26(8), 1559-1578.

Ishizaka, A., \& Labib, A. (2011). Review of the main developments in the analytic hierarchy process. Expert Systems with Applications, 38(11), 14336-14345.

Ju, S., \& Lee, Y. (2010). Experiences of family maltreatment by Korean children in Korean National Protective Services. Child Abuse and Neglect, 34(1), 18-27.

Krug, E. G., Dahlberg, L. L., Mercy, J. A., Zwi, A. B., \& Lozano, R. (2002). Relatório mundial sobre violência e saúde. Retrieved January 7, 2016, from http://www.opas. org.br/cedoc/hpp/ml03/0329.pdf

Lima, J., \& Deslandes, S. F. (2015). Olhar da gestão sobre a implantação da ficha de notificação da violência doméstica, sexual e/outras violências em uma metrópole do Brasil. Saúde social, 24(2), 661-673.

Lin, Y., Tseng, M., Chiu, A. S. F., \& Wang, R. (2014). Implementation and performance evaluation of a firm's green supply chain management under uncertainty. Industrial Engineering and Management Systems, 13(1), 15-28.

Mardani, A., Jusoh, A., Nor, K. M. D., Khalifah, Z., Zakwan, N., \& Valipour, A. (2015). Multiple criteria decisionmaking techniques and their applications - a review of the literature from 2000 to 2014. Economic Research, 28(1), 516-571.

Meade, L. M., \& Presley, A. (2002). R\&D project selection using the analytic network process. IEEE Transactions on Engineering Management, 49(1), 59-66.

Meinck, F., Cluver, L. D., Boyes, M. E., \& Mhlongo, E. L. (2015). Risk and protective factors for physical and sexual abuse of children and adolescents in Africa: A review and implications for practice. Trauma, Violence, and Abuse, 16(1), 81-107. 
Minayo, M. C. S. (2001). Violência contra crianças e adolescentes: questão social, questão de saúde. Revista Brasileira de Saúde Materno Infantil, 1(2), 91-102.

Njaine, K. (1997). A produção da (des)informação sobre violência: análise de uma prática discriminatória [Production of (mis)information on violence: analysis of a discriminatory practice]. Cad. de Saúde Pública, 13(3), 405-414.

Nunes, A. J., \& Sales, M. C. V. (2016). Violência contra crianças no cenário brasileiro. Ciência e Saúde Coletiva, 21(3), 871-880.

Paixão, A. C. W., \& Deslandes, S. F. (2010). Análise de Política Públicas no Enfrentamento da Violência Sexual Infantojuvenil. Saúde e Sociedade, 19(1), 114-126.

Pfeiffer, L., Rosário, N. A., \& Cat, M. N. L. (2011). Violência contra crianças e adolescentes - proposta de classificação dos níveis de gravidade [Violence against children and adolescents - proposed classification of severity levels]. Revista Paulista de Pediatria, 29(4), 477-482.

Saaty, T. L. (1990). How to make a decision: The analytic hierarchy process. European Journal of Operational Research, 48(1), 9-26.

Rizzini, I., \& Pilotti, F. (2011). A arte de governar crianças. São Paulo: Cortez.

Saaty, T. L. (2009). Extending the measurement of tangibles to intangibles. International Journal of Information Technology \& Decision Making, 8(1), 7-27.

Saaty, T. L. (2013). The modern science of multicriteira decision making and its practical applications: The AHP/ ANP approach. Operations Research, 61(5), 1101-1118.

Saaty, T. L., \& Vargas, L. G. (2006). Decision making with the analytic network process: Economic, political, social and technological applications with benefits, opportunities, costs and risks. New York, NY: Springer.
Sevkli, M., Oztekin, A., Uysal, O., Torlak, G., Turkyilmaz, A., \& Delen, D. (2012). Development of a fuzzy ANP based SWOT analysis for the airline industry in Turkey. Expert Systems with Applications, 39(1), 14-24.

Silva, P. A., Lunardi, V. L., Lunard, G. L., Algeri, S., \& Souza, T. (2016). Reporting of violence against children and adolescents in a protective institution in southern brazil. Investigacion y Educacion En Enfermeria, 34(1), 152-161.

Silveira, T. B., Oliveira, A. M. N., Algeri, S., Susin, L. R. O., Baisch, A. L. M., Marques, L. A., \& Silva, P. A. (2016). The invisibility of psychological violence against children. Journal of Human Growth and Development, 26(3), 345-351.

Veronese, G., Castiglioni, M., Barola, G., \& Said, M. (2012). Living in the shadow of occupation: Life satisfaction and positive emotion as protective factors in a group of Palestinian school children. Children and Youth Services Review, 34(1), 225-233.

Vinodh, S., Anesh, R., \& Gautham, S. G. (2011). Application of fuzzy analytic network process for supplier selection in a manufacturing organisation. Expert Systems with Applications, 38(1), 272-280.

Waiselfisz, J. J. (2012). Mapa da Violência 2012: Crianças e adolescentes do Brasil. Rio de Janeiro: CEBELA, FLACSO.

Wu, C., \& Barnes, D. (2016). An integrated model for green partner selection and supply chain construction. Journal of Cleaner Production, 112(3), 2114-2132.

Yuksel, I., \& Dagdeviren, M. (2007). Using the analytic network process (ANP) in a SWOT analysis - A case study for a textile firm. Information Sciences, 177(16), 3364-3382.

Yüksel, İ., \& Dağdeviren, M. (2010). Using the fuzzy analytic network process (ANP) for Balanced Scorecard (BSC): A case study for a manufacturing firm. Expert Systems with Applications, 37(2), 1270-1278. 